Article

\title{
Edge Effects Reflect the Impact of the Agricultural Matrix on the Corticolous Lichens Found in Fragments of Cerrado Savanna in Central Brazil
}

\author{
Kelly Maria Zanuzzi Palharini ${ }^{1}$, Luciana Cristina Vitorino ${ }^{1, *(\mathbb{D},}$ \\ Gisele Cristina de Oliveira Menino ${ }^{2}\left(\mathbb{D}\right.$ and Layara Alexandre Bessa ${ }^{3, *}$ \\ 1 Laboratory of Agricultural Microbiology, Instituto Federal Goiano-Campus Rio Verde, \\ Highway Sul Goiana, Km 01, Rio Verde 75901-970, GO, Brazil; kellymaria.zp@gmail.com \\ 2 Herbarium of the Instituto Federal Goiano-Campus Rio Verde, Rio Verde 75901-970, GO, Brazil; \\ gisele.menino@ifgoiano.edu.br \\ 3 Laboratory of Plant Mineral Nutrition, Instituto Federal Goiano-Campus Rio Verde, \\ Rio Verde 75901-970, GO, Brazil \\ * Correspondence: luciana.vitorino@ifgoiano.edu.br (L.C.V.); layara.bessa@ifgoiano.edu.br (L.A.B.); \\ Tel.: +55-64-3620-5600 (L.C.V.)
}

Received: 14 July 2020; Accepted: 29 August 2020; Published: 1 September 2020

\begin{abstract}
Habitat fragmentation affects lichen communities by inducing edge effects, although the dispersal of pollutants by pesticide drift from commercial crops may also provoke alterations in community structure, due to the varying sensitivity of lichen morphotypes to pollutants. In this context, we tested the hypothesis that lichen morphotype richness and diversity, and the percentage area of the trunks covered by different lichen morphotypes are modified significantly at the edges of fragments of Cerrado vegetation inserted within the agricultural matrix. We evaluated habitat fragments representing different Cerrado formations (Cerradão, Cerrado sensu stricto, and seasonal semi-deciduous forest) as well as the Emas National Park, a prominent Cerrado conservation unit. We used Generalized Linear Mixed Models (GLMMs) to test the potential of the models compiled using a mixture of phytosociological and environmental parameters, including the species, the height of the host plant $(H)$, the circumference of its stem at breast height (CBH), total chlorophyll (TC), bark fissuring $(\mathrm{BF})$ and $\mathrm{pH}$, and illuminance (Lum), to explain the observed variation in the lichen morphotype richness and the percentage cover of the trunks by corticolous lichen morphotypes at the center and edge of the fragments. The central areas invariably had a greater diversity of morphotypes in all the fragments. The morphotypes considered highly sensitive to disturbance were not observed in edge areas, confirming a clear edge effect, as well as the influence of pesticide drift from the adjacent farmland matrix, on the structure of the lichen community. At both the edge and center sites, the larger trees (higher $\mathrm{CBH}$ ) with less fissured bark tended to have the greatest diversity of lichen morphotypes, and more acidic barks had the greatest lichen cover. The models tested indicated that the variable tree species is an important determinant of the observed patterns of lichen morphotype richness and cover, either on its own or in association with $\mathrm{pH}$ or $\mathrm{CBH}+\mathrm{pH}$. The analyses also indicated that all the variables tested are important in some way for the definition of the percentage cover of the host trunks. The present study contributes to the understanding of the diversity of the corticolous lichen communities in the remaining fragments of Cerrado vegetation and the effects of the agricultural matrix on this community. The lichen may thus play a role as indicators of impact on other species, these organisms may provide important insights for the further investigation of the disturbance caused by the agricultural matrix on the communities of other groups of organisms.
\end{abstract}

Keywords: diversity of lichens; lichen cover; lichen morphotype richness; Brazilian savanna; corticolous lichen 


\section{Introduction}

The morphological, anatomical, and physiological characteristics of the lichens make these organisms highly sensitive to alterations in the environment (e.g., [1-3]). Lichen are so sensitive, in fact, that their diversity has been proposed as a tool for the monitoring of fluctuations in the atmosphere and climate change, that is, as ecological indicators, on a global scale [4]. However, while atmospheric pollution in urban and industrial environments has been one of the principal modifiers of the diversity and vitality of lichens (e.g., [5-7]), in forest environments, habitat fragmentation has been identified as the principal determinant of modifications of the lichen community (e.g., [8,9]).

Habitat fragmentation results in the loss of habitats for species that require more isolated, stable forest conditions. For example, the foliose lichen Lobaria oregana is dependent on the microclimate of the forest interior [10]. The fragmentation of the landscape also interrupts gene flow between populations [11] and exposes species to edge effects. Murphy and Lovett-Doust [12] suggested that the impacts of changes in the size and shape of fragments on lichen species abundance and distribution may be mitigated or intensified by shifts in the structure, composition, and management of the matrix. In this case, the quality of the matrix may influence the dispersal, availability of resources, and the characteristics of the abiotic environment [13] in such a way that the loss of species may be exacerbated by the contrast between the structure of the matrix and that of the vegetation of the fragment [14].

The effects of the forest edge on epiphytic lichens are well studied (e.g., [15-17]), although little is known of these effects in fragments of Neotropical savanna, in particular, those inserted in agricultural matrices. Located on the great plateau of Central Brazil, the Brazilian Cerrado biome covers an area of 2 million $\mathrm{km}^{2}$, representing $23 \%$ of the country. This biome is characterized by xeromorphic vegetation that develops under a mean annual precipitation of $800-2000 \mathrm{~mm}$ (in more than $90 \%$ of the area), with an intense dry season during the southern winter (generally between April and September). Annual temperatures range from $18{ }^{\circ} \mathrm{C}$ to $28^{\circ} \mathrm{C}$, and the soils are mainly dystrophic, with a low $\mathrm{pH}$ and high aluminum and iron content $[18,19]$. Agriculture exerts a profound pressure on the savannas of the Cerrado biome, not only by fragmenting natural environments, but also dispersing large quantities of pollutants into the remaining fragments $[20,21]$. Large quantities of pesticides, heavy metals from fertilizers, and particulate material from crop burn-off are carried from areas of intensive agriculture by winds [22] in a process known as pesticide drift, which is facilitated further by the application of fertilizers and pesticides by aircraft. This pesticide drift reaches adjacent Cerrado fragments, where it can affect all the resident organisms [23-27]. As the lichen community is known to be the most sensitive component of this biota, our hypothesis is that the diversity of lichen morphotypes and their coverage of tree trunks in Cerrado fragments inserted in a farmland matrix will be affected significantly by pesticide drift, in particular at the edges of these fragments. Given this, we evaluated the diversity of lichen morphotypes in Cerrado fragments of three different formations, the Cerradão (savanna woodland), Cerrado sensu stricto, and Seasonal Semi-deciduous Forest, given that habitat diversity appears to be an important determinant of the diversity of lichen communities [28].

The structure of the substrate, such as its humidity, texture, $\mathrm{pH}$, host species and tree age, bark fissuring (BF), circumference of the stem at breast height (CBH) [29-33] (Table 1), and characteristics of the environment (illuminance, conservation, disturbance, and alterations), may also affect the occurrence of corticolous lichen [34,35]. The influence of these factors on the morphotype richness, diversity, or abundance of lichen is typically evaluated through the application of an Analysis of Variance (ANOVA) or Generalized Linear Models (GLMs). These approaches are prone to certain errors, however, given that they ignore random deviations in the variables (e.g., $\mathrm{pH}, \mathrm{CBH}, \mathrm{BF}$ ) and treat all the different variables as fixed factors that may be affected by pseudo-replication [36]. Given this, a more appropriate approach for the analysis of these data are Generalized Linear Mixed Models (GLMMs), which combine the desirable properties of two different approaches, that is, mixed linear models that incorporate random effects and GLMs, which are appropriate for non-normal data [37]. As the GLMMs are able to better represent the lichen morphotype richness and trunk cover, we constructed models 
that mix the different variables and evaluated the explanatory power of these variables both on their own and in combination with other variables, as factors that select for lichen richness and cover.

Table 1. List of abbreviations.

\begin{tabular}{cc}
\hline Abbreviation & Definition \\
\hline AIC & Akaike Information Criterion \\
$\triangle$ AIC & Delta Akaike Information Criterion \\
wAIC & Weight Akaike Information Criterion \\
ANOVA & Analysis of Variance \\
APG IV & Angiosperm Phylogeny Group \\
BF & Bark fissuring \\
C & Center \\
CBH & Circumference of the stem at breast height \\
CER & Cerradão \\
E & Edge \\
ENP & Emas National Park \\
FCI & Falker Chlorophyll Index \\
GLMs & Generalized Linear Models \\
GLMMs & Generalized Linear Mixed Models \\
$H$ & height of the host plant \\
$H^{\prime}$ & Shannon-Wiener diversity index \\
Lum & Illuminance \\
$r$ & Pearson correlation coefficient \\
SSC & Cerrado sensu stricto \\
SSF & Seasonal Semi-deciduous Forest \\
TC & Total chlorophyll \\
UPGMA & Unweighted Pair Group Method using Arithmetic averages \\
\hline &
\end{tabular}

Understanding the effects of substrate and environmental variables on lichen communities should contribute to the development of environmental monitoring strategies and effective measures for the management of the biodiversity of forest fragments. In addition, a better understanding of the ecological and evolutionary dynamics of the forest edge will be fundamental to the comprehension of the biological phenomena associated with the more intense environmental impacts that occur in more marginal areas [38]. In this context, the present study compares the response of the different lichen morphotypes, in terms of their diversity, richness, and percentage cover, at the edge and in the center of three fragments of Cerrado inserted within an agricultural matrix, and also in the Emas National Park (ENP), an important Cerrado conservation unit, with the principal objective of understanding how the agricultural matrix affects the different lichen morphotypes, in particular, at the edges of fragments of natural vegetation in this biome.

\section{Materials and Methods}

\subsection{Study Area}

Sampling was conducted at the edge (E) and in the center (C) of three fragments of Cerrado vegetation located in the rural zone of the municipality of Rio Verde, in Southwestern Goiás state, central Brazil (Figure 1). The fourth site was the ENP, also in Southwestern Goiás. Each fragment represented a different Cerrado formation, that is, the Cerradão (CER: $E=17^{\circ} 19^{\prime} 27.5^{\prime \prime} \mathrm{S}, 51^{\circ} 33^{\prime} 25.3^{\prime \prime} \mathrm{W}$; $\mathrm{C}=17^{\circ} 20^{\prime} 01.6^{\prime \prime} \mathrm{S}, 51^{\circ} 33^{\prime} 36.58^{\prime \prime} \mathrm{W}$ ), Seasonal Semi-deciduous Forest (SSF: $\mathrm{E}=17^{\circ} 35^{\prime} 18.46^{\prime \prime} \mathrm{S}$, $50^{\circ} 47^{\prime} 56.60^{\prime \prime} \mathrm{W} ; \mathrm{C}=17^{\circ} 35^{\prime} 23.31^{\prime \prime} \mathrm{S}, 50^{\circ} 47^{\prime} 51.44^{\prime \prime} \mathrm{W}$ ), and Cerrado sensu stricto (SSC: $\mathrm{E}=17^{\circ} 31^{\prime} 21.10^{\prime \prime} \mathrm{S}$, $50^{\circ} 49^{\prime} 31.20^{\prime \prime} \mathrm{W} ; \mathrm{C}=17^{\circ} 31^{\prime} 30.1^{\prime \prime} \mathrm{S}, 50^{\circ} 49^{\prime} 29.20^{\prime \prime} \mathrm{W}$ ). In the ENP, the edge site is located at $18^{\circ} 20^{\prime} 38.22^{\prime \prime} \mathrm{S}$, $52^{\circ} 45^{\prime} 44.03^{\prime \prime} \mathrm{W}$, and the central site, at $18^{\circ} 14^{\prime} 28.7^{\prime \prime} \mathrm{S}, 52^{\circ} 52^{\prime} 55.7^{\prime \prime} \mathrm{W}$ (Figure 1 ).

The Cerradão is a woodland formation with xeromorphic features, which includes species found typically in Cerrado sensu stricto, in addition to species found in the forest. While the physiognomy 
of the Cerradão is that of a forest, then, its composition is more similar to that of the Cerrado [39]. The Cerrado sensu stricto is a savanna formation composed of short trees, with characteristically contorted trunks, often presenting signs of fire damage. The Seasonal Semi-deciduous Forest is a typical dry forest formation, in which the plants tend to lose their leaves during the dry season, with a $20-50 \%$ loss of foliage in the canopy during the dry season [40]. The fragments were selected based on the type of Cerrado formation and the history of being adjacent to areas of intensive agriculture for more than 10 consecutive years, where the margin of farmland extends for at least $500 \mathrm{~m}$, perpendicularly, from the edge of the fragment. The study area in the ENP was located within an area of Cerrado sensu stricto.

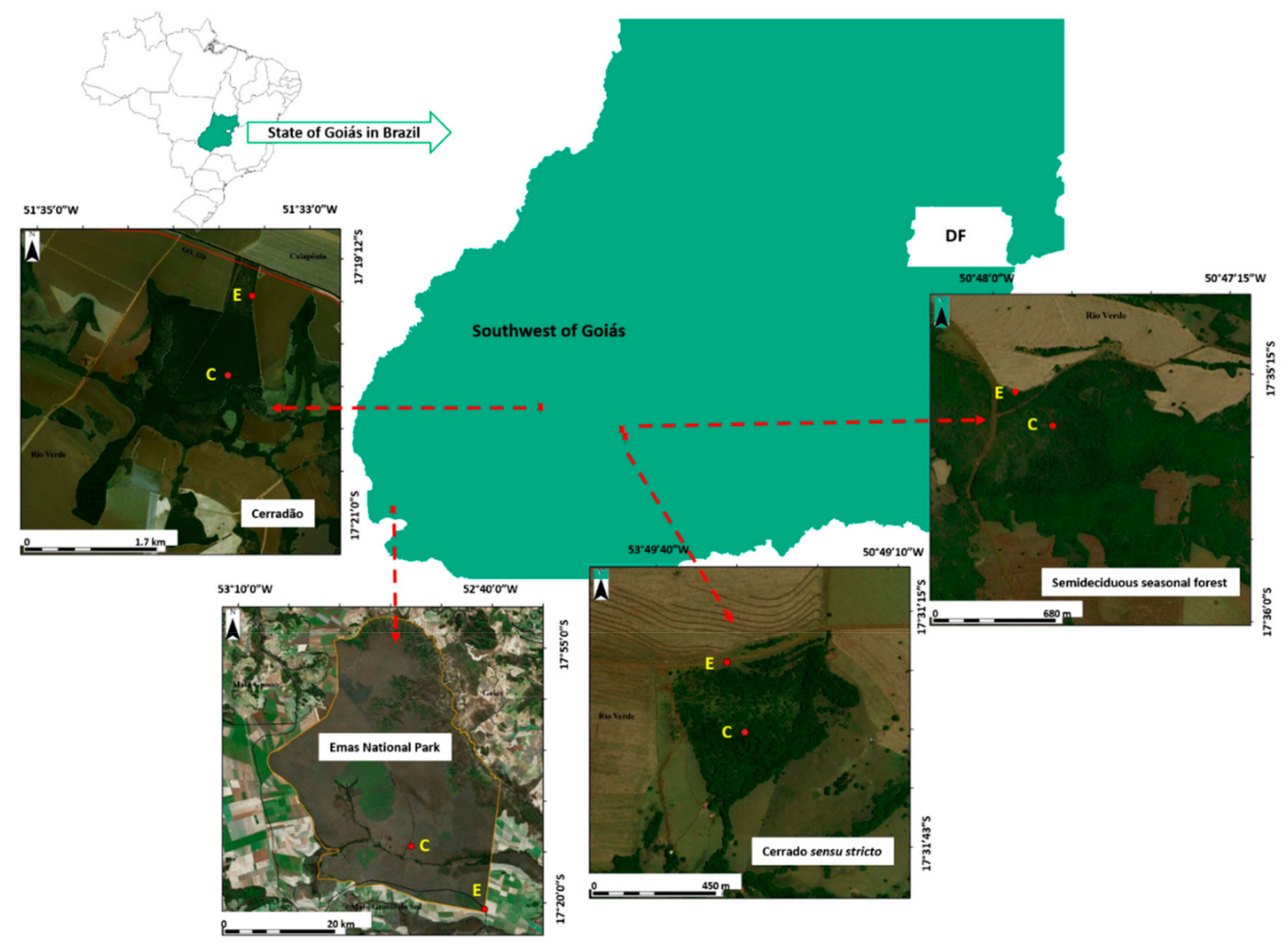

Figure 1. Location of the center (C) and edge (E) sites in the three Cerrado fragments (Cerradão, Seasonal Semideciduous Forest, and Cerrado sensu stricto) and the Emas National Park, in Southwestern Goiás, central Brazil, visited for the collection of data on the phytosociology of the habitats and the local lichen community. DF = Federal District.

\subsection{Collection of the Phytosociological Data}

For control and identification, a total of 200 trees were marked with aluminum tags within each study area (100 trees at the edge site and 100 at the center site). The trees were marked randomly during walks along four parallel trails, spaced at 5-m intervals (Figure 2). To be included in the sample, the trees had to have a stem circumference of over $10 \mathrm{~cm}$ at a height of $30 \mathrm{~cm}$ above the ground.

Each sampled tree was measured to determine its height $(H)$ in meters and the circumference of its stem at breast height (CBH) in centimeters. The total chlorophyll (TC) of the leaves was also determined, as described below. The height was estimated visually, using a pole of a known length for comparison. The CBH was measured using a surveyor's tape. The total leaf pigment was determined by the sum of the chlorophyll $a$ and $b$ indices using a portable ClorofiLOG1030 ${ }^{\circledR}$ reader (Falker ${ }^{\circledR}$, Porto Alegre, RS, Brazil), with the data being expressed as a Falker Chlorophyll Index (FCI) [41]. The plant species were identified in the field, whenever possible, and whenever this was not possible, samples were collected using a tree trimmer and pressed for later identification using taxonomic keys [42-44] and consultations with botanists, when necessary. The taxa were classified using the 
APG IV [45] system and the scientific names were conferred according to the Flora do Brasil database (http://floradobrasil.jbrj.gov.br; Supplementary Table S1).

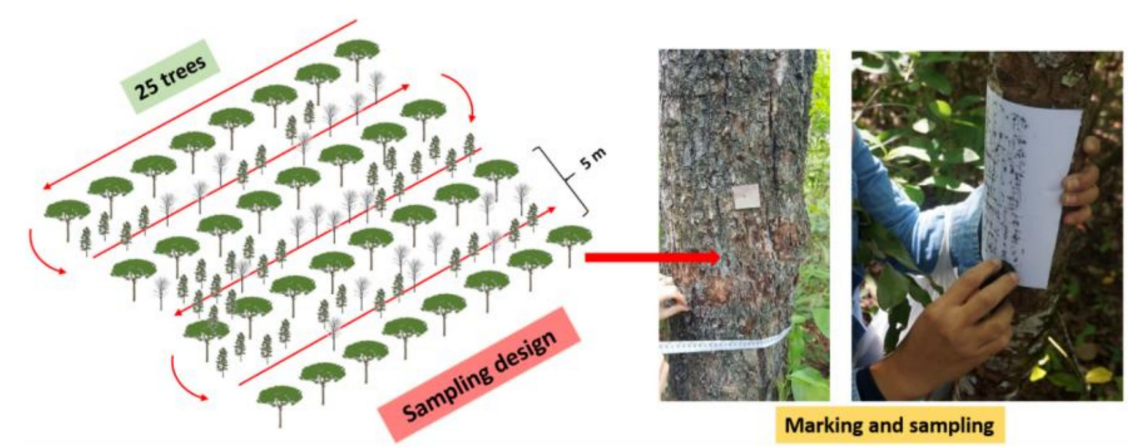

Figure 2. Experimental design for the sampling of 100 trees in the center and 100 trees at the edge of three fragments of Cerrado and the Emas National Park.

The $\mathrm{pH}$ of the bark was also determined, as was the degree of bark fissuring (BF) of each tree. To determine the $\mathrm{pH}$ of each tree, a sample of approximately $5 \mathrm{~cm} \times 2.5 \mathrm{~cm}$ of the outermost layer of the bark was obtained (see [46]). These bark samples were broken manually into pieces of approximately $0.5 \mathrm{~cm} \times 0.5 \mathrm{~cm}$, from which any residue of lichen or sap was removed. A $0.5 \mathrm{~g}$ aliquot of each bark sample was then treated with $5 \mathrm{~mL}$ of deionized water and covered to ensure that no atmospheric $\mathrm{CO}_{2}$ was dissolved in the water. These samples were left for $24 \mathrm{~h}$ and then filtered, with the $\mathrm{pH}$ of the filtered liquid being measured using a bench-top pH-meter (Gehaka ${ }^{\circledR}$, São Paulo, Brazil).

The degree of bark fissuring (BF) was estimated using the method proposed by McDonald et al. [47], which involves pressing a sheet of white paper against the bark and rubbing charcoal over a $5 \mathrm{~cm} \times 7 \mathrm{~cm}$ section of the paper. This was done on the tree stem, in areas with a minimum possible amount of lichen or sap. Each sheet was processed using the ImageJ image treatment software (National Institutes of Health, Bethesda, MD, USA) [48] to estimate the percentage of the area of the bark corresponding to the fissures (paper unmarked by the charcoal). For this, a standard area of $5 \mathrm{~cm} \times 5 \mathrm{~cm}\left(25 \mathrm{~cm}^{2}\right)$ was digitized, focusing on the central portion of the rub, as standard. This area was transformed to binary black, and the percentage of white pixels was calculated, based on their area, in $\mathrm{cm}^{2}$. This percentage corresponds to the degree of bark fissuring.

At each center and edge site, the illuminance (Lum) was verified in lux, using a digital MLM-1011 luxmeter (Minipa ${ }^{\circledR}$, Brazil). The data were obtained at five points selected randomly within each study area (for mean values see Supplementary Table S2).

\subsection{Collection of the Data on the Lichen Community}

The frequency of the different lichen morphotypes and the percentage of lichen cover were evaluated on the trunk of each marked tree. Five macrolichen morphotypes were recognized: crustose (flat, tightly adhered, crust-like lichen), foliose (leafy lichen), fruticose (shrubby lichen), dimorphic (combination of crustose and fruticose), and filamentous lichen. The percentage of lichen cover was estimated visually in three $10 \mathrm{~cm} \times 15 \mathrm{~cm}$ panels on the trunk at heights of $0-50 \mathrm{~cm}, 51-150 \mathrm{~cm}$, and 151-200 cm above the ground, always on the side of the tree facing the nearest fragment edge (method adapted from Benítez et al. [49]). The lichen cover of the trunks was estimated as a percentage of the panels covered by lichen, with the mean of the three panels providing the value for each tree. The data on the frequency of lichen morphotypes were used to estimate the abundance, richness, and Shannon-Wiener [50] diversity of the lichen in the different study areas. This index was chosen because of its sensitivity to rare species [51], given that filamentous and dimorphic lichen were rare in our samples. 
The Shannon-Wiener diversity index was calculated using the formula:

$$
H^{\prime}=-\sum_{i=1}^{S} p i \ln p i
$$

where: $p i=$ the relative abundance of the $i$ th lichen morphotype, calculated by dividing the frequency of morphotype $i$ by the total number of individuals in the community and $S=$ the number de morphotypes (richness).

\subsection{Statistical Analyses}

The data on the lichen morphotype richness and cover, obtained at the center and edge sites were compared within each fragment, and the total dataset for the fragments was compared with that of the ENP, which was considered the control area for the analyses, given that this protected area has been preserved for almost 60 years since its establishment in 1961, through federal decree number 49,874. For this, a one-way ANOVA was applied and pairwise comparisons were based on the standard Student $t$ criterion, with a $p=0.05$ significance level.

The mean values for the phytosociological structure variables $(H, \mathrm{CBH}, \mathrm{pH}, \mathrm{BF}, \mathrm{TC}$, and Lum) and the lichen richness and cover obtained in the center and edge sites were evaluated using Pearson's correlation coefficient $(r)$, with a significance of $p=0.05$. All these analyses were run in the $\mathrm{R}$ environment, version 3.6.1 [52].

The effects of the phytosociological structure and the plant species on the lichen richness and cover were evaluated using GLMMs. For this, the explanatory variables were Species, $H, \mathrm{CBH}, \mathrm{pH}, \mathrm{BF}$, and TC. A range of models were compiled with a different combination of these variables, as well as a null model to determine whether random effects could account for the response variables. The variables of the phytosociological structure were adjusted as random factors and the species were considered to be fixed factors. The analyses were run in the $M C M C g l m m$ package $[53,54]$ implemented in R. We used the Akaike Information Criterion (AIC) and the Delta AICci ( $\triangle \mathrm{AICci}$, in which $i$ represents each model) to select the model that best explained the variation observed in the lichen parameters in the different fragments. The value of $\triangle \mathrm{AIC}$ i is calculated by the difference between the AICc (the AIC corrected by sample size and the number of parameters) for the ith model and the lowest AICc observed overall, where the model with the lowest AICc was considered to be the most plausible explanation of the observed patterns [55]. We also determined the Akaike (wAICc) weight, which represents the relative contribution of the $i$ th model to the explanation of the observed pattern, given a set of competing models. All the models with $\triangle \mathrm{AICc}<2$ were considered to be equally plausible as an explanation for the observed pattern [55].

A matrix of similarity was compiled to determine the similarities or differences among the study areas, based on the abundance and richness of lichen morphotypes, illuminance, and the host tree species found in each fragment. The similarity index was obtained using the Pearson correlation coefficient, with the $r$ values being transformed by $d=(1-r) \times 100$, to estimate the distance $(d)$ values. The dendrogram was then generated using the Unweighted Pair Group Method using Arithmetic averages (UPGMA), with the adjustment between the distance matrix and the dendrogram being estimated using a cophenetic correlation coefficient [56]. This analysis was run in the DendroUPGMA software [57].

\section{Results}

A total of 1918 lichens were recorded at the central sites during the present study period (Figure 3a). The greatest total frequency of lichen at the central sites was observed in the SSC fragment (592 specimens), followed by the CER (514 specimens), SSF (426 specimens), and the ENP (386 specimens). At the edge sites, a total of 1182 lichens were recorded (Figure 3b). The greatest 
frequency of lichen at the edge sites was also recorded in the SSC fragment (390 specimens), followed by the ENP (298 specimens), SSF (268 specimens), and CER (226 specimens).
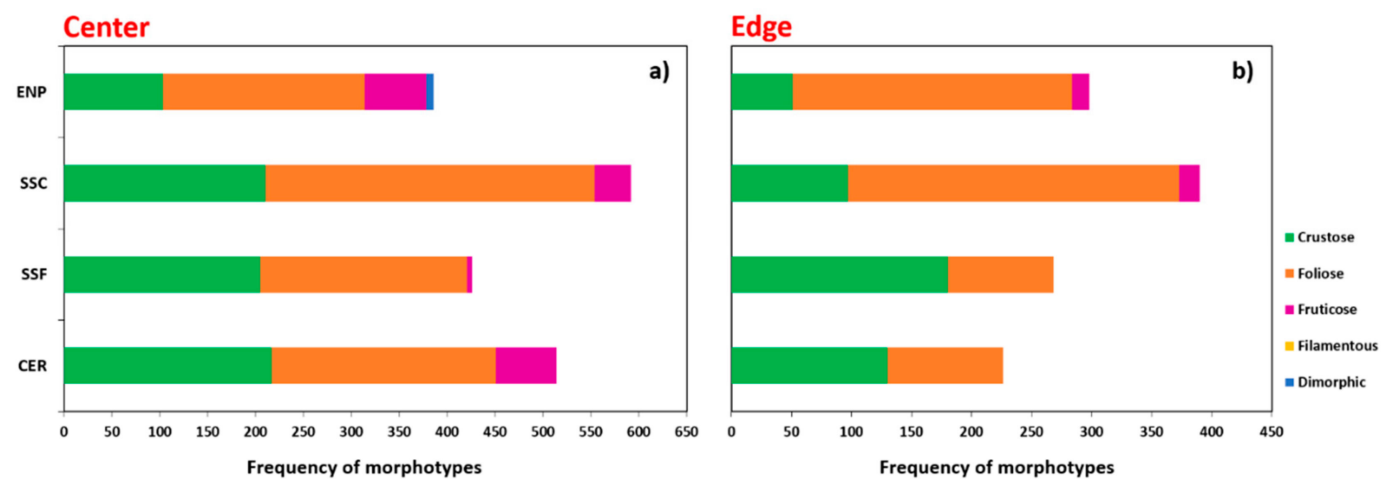

Figure 3. Frequency of lichen morphotypes observed no center (a) and edge (b) of three fragments of Cerrado and the Emas National Park (ENP).

The foliose morphotype was the most frequent at both the center and the edge sites in all the study areas, with the greatest frequency of this morphotype (344 specimens) being recorded at the edge site of the SSR fragment. The second most common morphotype was the crustose type, which was most frequent at the edge site in the CER fragment (217 specimens). The fruticose morphotype, by contrast, was more frequent at the center of the fragments and was most frequent, overall, in the ENP (64 specimens). The dimorphic morphotype was recorded only in the center of the ENP (8 specimens), while the filamentous morphotype was not observed in any of the study areas (Figure 3a,b).

The overall Shannon-Wiener diversity index for all the study sites combined was $H^{\prime}=0.889$, although the index was higher for the center sites $\left(H^{\prime}=0.943\right)$ in comparison with the edge sites $\left(H^{\prime}=0.775\right)$. The highest index per area was recorded for the CER fragment $\left(H^{\prime}=0.924\right)$, followed by the ENP $\left(H^{\prime}=0.915\right), \operatorname{SSC}\left(H^{\prime}=0.815\right)$, and SSF $\left(H^{\prime}=0.723\right)$.

The mean richness (number) of lichen morphotypes was invariably higher at the center sites of each fragment in comparison with the edge sites (Figure 4a). However, the mean richness recorded at the edge sites of all the fragments combined (2.95) was similar to that of the Edge site in the ENP (2.98). The mean morphotype richness recorded in the center of the ENP (3.86) was lower than that recorded in the central areas of the fragments (5.11) (Figure $4 \mathrm{~b}$ ). The lichen cover of the trunks was also greater in the central areas of the fragments, except in the SSC, where the means recorded for the center $(26.61 \%)$ and edge (26.13\%) were similar (Figure $4 \mathrm{c}$ ). A similar pattern was also observed when we compared the mean cover recorded in the fragments with that observed in the ENP, where the means recorded at the edges were similar (24.1\% in the fragments and $17.8 \%$ in the ENP), but the mean value recorded in the central area of the fragments $(48.3 \%$ ) was greater than that found in the ENP (32.9\%) (Figure 4d).

A positive correlation was observed between the $\mathrm{CBH}$ and the lichen morphotype richness at both the center $(r=0.142 ; p=0.012 *)$ and the edge $(r=0.175 ; p=0.003 * *)$ of the fragments (Table 2). The variable BF was also important for the definition of the lichen richness at both the center $(r=-0.152$, $\left.p=0.007^{* *}\right)$ and edge sites $\left(r=-0.170, p=0.004^{* *}\right)$, albeit negatively in both cases. When we analyzed the center and edge together, however, we found only negative correlations with lichen richness, for TC $\left(\mathrm{r}=-0.179, p=0.003^{* *}\right)$ and $\operatorname{Lum}\left(\mathrm{r}=-0.171, p=0.004^{* *}\right)$. In the centers of the fragments, we also observed a tendency for a greater lichen richness on taller trunks $\left(\mathrm{r}=0.171, p=0.002^{* *}\right)$ and in areas with lower illuminance $\left(\mathrm{r}=-0.476, \mathrm{p}=0.034^{*}\right)$, whereas at the edge, barks with more acidic trunks, that is, a lower $\mathrm{pH}$, had a greater morphotype richness $(\mathrm{r}=-0.115, p=0.043 *)$. 

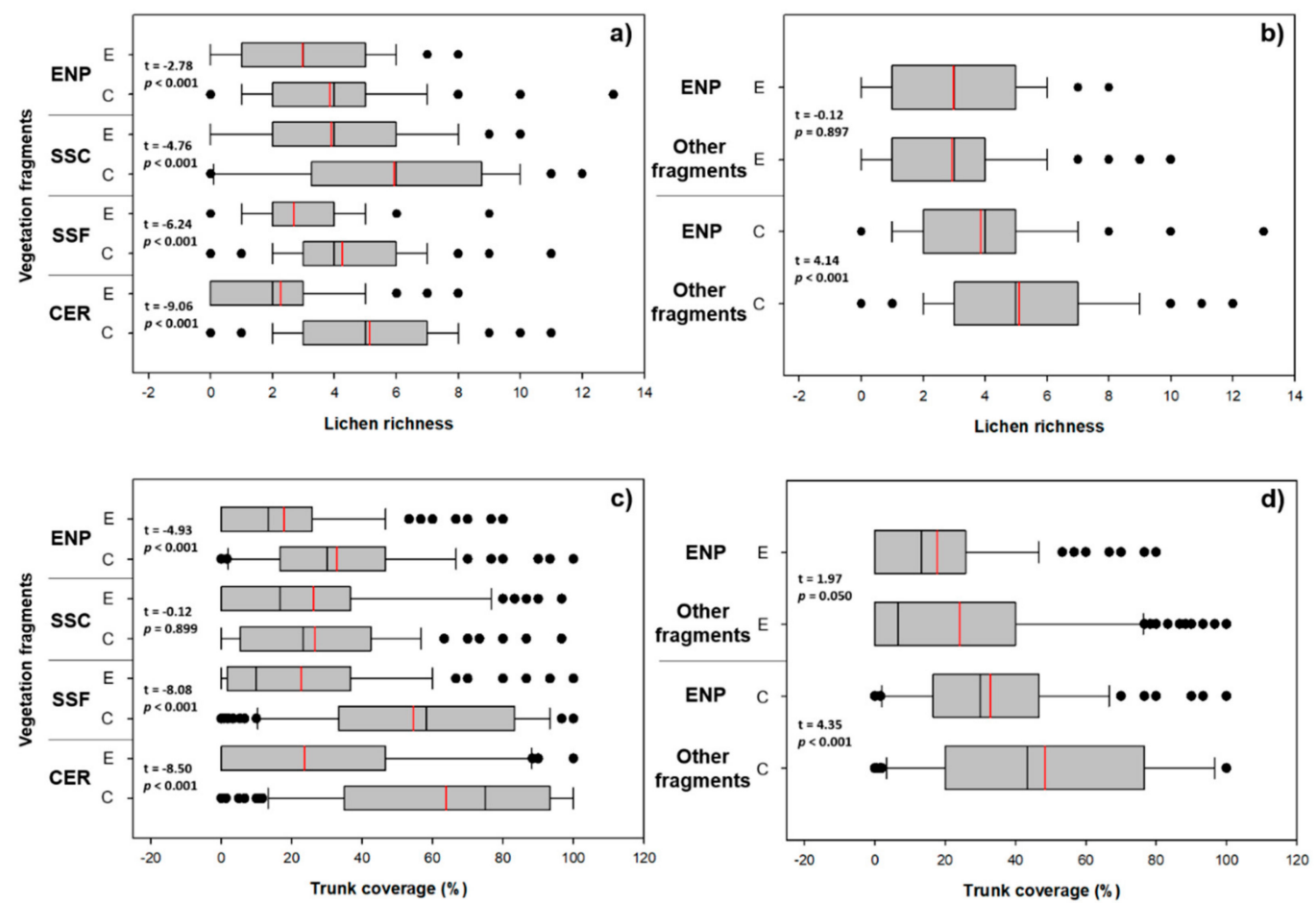

Figure 4. Lichen morphotype richness $(\mathbf{a}, \mathbf{b})$ and percentage cover $(\mathrm{c}, \mathrm{d})$ of the trunk per morphotype observed in the center (C) and edge (E) of three fragments of Cerrado and the Emas National Park (ENP). The black lines in the boxes are the medians and the red lines, the means. The points located outside the boxes are outliers. The bars indicate the interval between the maximum and minimum values.

Table 2. Correlation between phytosociological variables ( $\mathrm{H}, \mathrm{CBH}, \mathrm{pH}, \mathrm{BF}, \mathrm{TC}$, and Lum), the richness of lichen morphotypes, and the percentage of lichen cover on the trunks at the center and edge sites of fragments of Cerradão (CER), Seasonal Semi-deciduous Forest (SSF), and Cerrado sensu stricto (SSC), and the Emas National Park (ENP). $\mathrm{CBH}=$ Circumference at breast height; $H=$ height; $\mathrm{pH}=\mathrm{pH}$ of the bark; $\mathrm{TC}=$ Total Chlorophyll; $\mathrm{BF}=$ Bark fissures, and Lum = Illuminance.

\begin{tabular}{|c|c|c|c|c|c|c|}
\hline \multirow{2}{*}{ Model } & \multicolumn{2}{|c|}{ Center } & \multicolumn{2}{|c|}{ Edge } & \multicolumn{2}{|c|}{ Total } \\
\hline & $\mathbf{r}$ & $p$ & $\mathbf{r}$ & $p$ & $\mathbf{r}$ & $p$ \\
\hline CBH vs. Richness & 0.142 & $0.012 *$ & 0.175 & $0.003 * *$ & 0.068 & 0.097 \\
\hline H vs. Richness & 0.171 & $0.002 * *$ & 0.037 & 0.537 & 0.077 & 0.061 \\
\hline pH vs. Richness & 0.093 & 0.100 & -0.179 & $0.003^{* *}$ & -0.029 & 0.488 \\
\hline TC vs. Richness & -0.183 & $0.001 * *$ & -0.030 & 0.621 & -0.128 & $0.002 * *$ \\
\hline BF vs. Richness & -0.152 & $0.007^{* *}$ & -0.170 & $0.004^{* *}$ & -0.055 & 0.178 \\
\hline Lum vs. Richness & -0.476 & $0.034 *$ & -0.380 & 0.098 & -0.598 & $0.005^{* *}$ \\
\hline CBH vs. Cover & -0.013 & 0.821 & 0.127 & $0.033 *$ & -0.009 & 0.825 \\
\hline$H$ vs. Cover & -0.012 & 0.838 & 0.060 & 0.318 & -0.010 & 0.809 \\
\hline pH vs. Cover & -0.115 & $0.043 *$ & -0.158 & $0.008^{* *}$ & -0.140 & $0.001^{* *}$ \\
\hline TC vs. Cover & -0.187 & $0.001 * *$ & -0.078 & 0.192 & -0.148 & $0.001 * *$ \\
\hline BF vs. Cover & -0.062 & 0.278 & -0.025 & 0.670 & 0.038 & 0.361 \\
\hline Lum vs. Cover & -0.291 & 0.214 & -0.414 & 0.069 & -0.519 & $0.001 * *$ \\
\hline
\end{tabular}

* Significant at $5 \%$;* Significant at $1 \%$. Significant correlations are shown in bold.

In edge areas, the CBH was also correlated positively with the lichen trunk cover $(r=0.127$, $\left.p=0.033^{*}\right)$, that is, trees with a greater girth tend to host more lichen morphotypes and have trunks more covered with lichen (Table 2). The $\mathrm{pH}$ of the bark was also correlated negatively with the lichen cover at both the center $\left(\mathrm{r}=-0.115, p=0.043^{*}\right)$ and edge $\left(\mathrm{r}=-0.158, p=0.008^{* *}\right)$ of the fragments. When the center and edge are analyzed together, the variables $\mathrm{pH}(\mathrm{r}=-0.140, p=0.001 * *)$, TC $\left(r=-0.148, p=0.001^{* *}\right)$, and $\operatorname{Lum}\left(r=-0.519, p=0.001^{* *}\right)$ all had a negative effect on lichen trunk cover. 
The GLMM identified a number of different plausible models to explain the variation observed in the total lichen morphotype richness: Species, Species $+\mathrm{BF}$, Species $+\mathrm{pH}$, Species $+\mathrm{pH}+\mathrm{BF}$, Species $+\mathrm{TC}$, Species $+H+\mathrm{BF}$, Species $+\mathrm{TC}+\mathrm{BF}$, Species $+\mathrm{CBH}+\mathrm{BF}$, and Species $+\mathrm{TC}+\mathrm{pH}$ (Table 3), although the highest wAIC was observed in the model that considered only the species. When the lichen richness of the center sites was considered alone, the most plausible models were: Species $+\mathrm{pH}$, Species $+\mathrm{TC}+\mathrm{pH}$, Species, Species $+\mathrm{TC}$, Species $+H+\mathrm{pH}$, and Species $+\mathrm{CBH}+\mathrm{pH}$, with the greatest wAIC value being recorded for the Species $+\mathrm{pH}$ model. For the edge sites, the best models were: Species $+\mathrm{CBH}+\mathrm{pH}$, Species $+\mathrm{CBH}$, Species $+\mathrm{CBH}+\mathrm{BF}$, and Species $+\mathrm{TC}+\mathrm{CBH}$. In addition to the variable Species, then, $\mathrm{pH}$ and $\mathrm{CBH}$ were also present in the majority of the models that best explain the observed patterns of the lichen richness.

Table 3. Selection of the models generated for the competing hypotheses for the explanation of the variation in the total lichen morphotype richness, the richness at the center and edge of three fragments of Cerrado and the Emas National Park (ENP). CBH = Circumference at breast height; $H$ = height; $\mathrm{pH}=\mathrm{pH}$ of the bark; $\mathrm{TC}=$ Total Chlorophyll; $\mathrm{BF}=$ Bark fissures, and Lum = Illuminance. The models with $\triangle$ AICc $<2$ are highlighted in bold type. $\mathrm{k}=$ the function dimension and $\beta=$ fixed effects.

\begin{tabular}{|c|c|c|c|c|c|}
\hline Model & $\Delta \mathrm{AICc}$ & wAIC & $\mathbf{k}$ & $\beta$ & $p$ \\
\hline & \multicolumn{5}{|c|}{ Richness Total } \\
\hline Species & 0 & 0.1517 & 4 & 0.1061 & - \\
\hline Species + BF & 0.2 & 0.1352 & 5 & 0.1185 & 0.0550 \\
\hline Species + pH & 0.7 & 0.1072 & 5 & 0.1060 & 0.8900 \\
\hline Species $+\mathrm{pH}+\mathrm{BF}$ & 0.9 & 0.0954 & 6 & 0.1185 & 0.1574 \\
\hline Species + TC & 1.2 & 0.0845 & 5 & 0.0927 & 0.2818 \\
\hline Species $+H+\mathrm{BF}$ & 1.6 & 0.0691 & 6 & 0.0988 & 0.0548 \\
\hline Species + TC + BF & 1.8 & 0.0629 & 6 & 0.1070 & 0.1068 \\
\hline Species + CBH + BF & 1.8 & 0.0622 & 6 & 0.0816 & 0.0531 \\
\hline Species $+\mathrm{TC}+\mathrm{pH}$ & 1.9 & 0.0595 & 6 & 0.0927 & 0.5564 \\
\hline Species $+H$ & 2.3 & 0.0484 & 5 & 0.0903 & 0.2713 \\
\hline Species $+H+\mathrm{pH}$ & 2.9 & 0.0351 & 6 & 0.0899 & 0.5300 \\
\hline Species + CBH & 3.1 & 0.0319 & 5 & 0.0844 & 0.4011 \\
\hline Species $+\mathrm{CBH}+\mathrm{pH}$ & 3.8 & 0.0225 & 6 & 0.0844 & 0.6982 \\
\hline Species $+\mathrm{TC}+\mathrm{CBH}$ & 4.2 & 0.0184 & 6 & 0.0696 & 0.3805 \\
\hline Species $+\mathrm{CBH}+H$ & 5.5 & 0.0099 & 6 & 0.0877 & 0.5425 \\
\hline Species $+\mathrm{TC}+\mathrm{CBH}+H+\mathrm{pH}+\mathrm{BF}$ & 6.4 & 0.0062 & 9 & 0.0728 & 0.2121 \\
\hline \multirow[t]{2}{*}{ Species $+\mathrm{TC}+\mathrm{H}$} & 3679.1 & $<0.001$ & 6 & -4.6210 & 1.0000 \\
\hline & \multicolumn{5}{|c|}{ Center } \\
\hline Species $+\mathrm{pH}$ & 0 & 0.1934 & 5 & 0.3165 & 0.3194 \\
\hline Species $+\mathrm{TC}+\mathrm{pH}$ & 0.7 & 0.1350 & 6 & 0.2984 & 0.4002 \\
\hline Species & 0.8 & 0.1272 & 4 & 0.3349 & - \\
\hline Species + TC & 1.6 & 0.0882 & 5 & 0.3172 & 0.3656 \\
\hline Species $+H+$ pH & 1.6 & 0.0865 & 6 & 0.3418 & 0.3232 \\
\hline Species $+\mathrm{CBH}+\mathrm{pH}$ & 1.9 & 0.0737 & 6 & 0.3274 & 0.3501 \\
\hline Species $+H$ & 2.2 & 0.0651 & 5 & 0.3599 & 0.2120 \\
\hline Species + CBH & 2.8 & 0.0475 & 5 & 0.3458 & 0.3022 \\
\hline Species $+\mathrm{pH}+\mathrm{BF}$ & 2.9 & 0.0444 & 6 & 0.3131 & 0.6019 \\
\hline Species $+\mathrm{TC}+\mathrm{CBH}$ & 3.5 & 0.0332 & 6 & 0.3284 & 0.3869 \\
\hline Species + BF & 3.8 & 0.0293 & 5 & 0.3310 & 0.8638 \\
\hline Species $+\mathrm{CBH}+H$ & 4.5 & 0.0208 & 6 & 0.3586 & 0.4497 \\
\hline Species + TC + BF & 4.5 & 0.0205 & 6 & 0.3121 & 0.6476 \\
\hline Species $+H+\mathrm{BF}$ & 5.0 & 0.0162 & 6 & 0.3524 & 0.4235 \\
\hline Species $+\mathrm{CBH}+\mathrm{F}$ & 5.4 & 0.0131 & 6 & 0.3354 & 0.5080 \\
\hline Species $+\mathrm{TC}+\mathrm{CBH}+H+\mathrm{pH}+\mathrm{BF}$ & 7.0 & 0.0059 & 9 & 0.3097 & 0.6081 \\
\hline Species $+\mathrm{TC}+\mathrm{H}^{1}$ & 1874.6 & $<0.001$ & 6 & 4.0750 & 1.0000 \\
\hline
\end{tabular}


Table 3. Cont.

\begin{tabular}{cccccc}
\hline Model & DAICc & wAIC & k & $\boldsymbol{\beta}$ & $p$ \\
\hline & \multicolumn{5}{c}{ Edge } \\
\hline Species + CBH + pH & $\mathbf{0 . 0}$ & $\mathbf{0 . 3 2 1 8}$ & $\mathbf{6}$ & $\mathbf{- 0 . 3 5 3 2}$ & $<0.001^{* * *}$ \\
Species + CBH & $\mathbf{0 . 2}$ & $\mathbf{0 . 2 9 2 8}$ & $\mathbf{5}$ & $\mathbf{- 0 . 3 5 1 4}$ & $<0.001^{* * *}$ \\
Species + CBH + BF & $\mathbf{1 . 8}$ & $\mathbf{0 . 1 2 9 3}$ & $\mathbf{6}$ & $\mathbf{- 0 . 3 2 1 8}$ & $<0.001^{* * *}$ \\
Species + TC + CBH & $\mathbf{1 . 9}$ & $\mathbf{0 . 1 2 3 7}$ & $\mathbf{6}$ & $\mathbf{- 0 . 3 5 9 9}$ & $<0.001^{* * *}$ \\
Species + CBH + H & 2.5 & 0.0930 & 6 & -0.3516 & $<0.001^{* * *}$ \\
Species + TC + CBH + H + pH + BF & 5.7 & 0.0189 & 9 & -0.3217 & $0.0049^{* *}$ \\
Species + H + pH & 7.7 & 0.0069 & 6 & -0.2886 & $0.0338^{*}$ \\
Species + H & 8.7 & 0.0042 & 5 & -0.2878 & $0.0176^{*}$ \\
Species + H + BF & 9.2 & 0.0033 & 6 & -0.2513 & $0.0143^{*}$ \\
Species + pH & 10.9 & 0.0014 & 5 & -0.3799 & 0.4000 \\
Species + pH + BF & 11.0 & 0.0013 & 6 & -0.3363 & 0.1000 \\
Species & 11.5 & 0.0010 & 4 & -0.3767 & - \\
Species + BF & 11.6 & $<0.001$ & 5 & -0.3331 & 0.0683 \\
Species + TC + PH & 12.6 & $<0.001$ & 6 & -0.3887 & 0.6000 \\
Species + TC & 13.2 & $<0.001$ & 5 & -0.3849 & 0.7000 \\
Species + TC + BF & 13.4 & $<0.001$ & 6 & -0.3343 & 0.2000 \\
Species + TC + H & 1792.1 & $<0.001$ & 6 & 2.1170 & 1.0000 \\
\hline
\end{tabular}

${ }^{*}$ Significant at $5 \% ;{ }^{* *}$ Significant at $1 \% ;{ }^{* * *}$ Significant at $0.1 \%$.

The model which includes all the variables tested (Species $+\mathrm{TC}+\mathrm{CBH}+\mathrm{H}+\mathrm{pH}+\mathrm{BF}$ ) was the most plausible to explain the variation observed in the total percentage lichen cover of the tree trunks (Table 4). This means that all the variables were important, in some way, for the definition of the total cover, although, when the center and edge were analyzed separately, this model was only the most plausible for the patterns recorded at the edge sites, whereas the model with the lowest $\triangle \mathrm{AICC}$ for the center sites was that which included only the variable Species, indicating that some of the plant species found in this type of vegetation have a greater propensity for colonization by lichen than others. The Species $+\mathrm{TC}+\mathrm{CBH}+H+\mathrm{pH}+\mathrm{BF}$ model was the second most plausible for the center sites, however.

Table 4. Selection of the models generated for the competing hypotheses used to explain the variation in the total lichen cover on the trunks of the host trees at the center and edge of three fragments of Cerrado and the Emas National Park (ENP). CBH = Circumference at breast height; $H$ = height; $\mathrm{pH}=\mathrm{pH}$ of the bark; $\mathrm{TC}=$ Total Chlorophyll; $\mathrm{BF}=$ Bark fissures, and Lum = Illuminance. The models with $\triangle \mathrm{AICc}<2$ are highlighted in bold type.

\begin{tabular}{cccccc}
\hline Model & $\boldsymbol{\Delta A I C c}$ & wAIC & $\mathbf{k}$ & $\boldsymbol{\beta}$ & $\boldsymbol{p}$ \\
\hline & Total Cover & & & & \\
\hline Species + TC + CBH + H + pH + BF & $\mathbf{0 . 0}$ & $\mathbf{1 . 0}$ & $\mathbf{9 . 0}$ & $\mathbf{0 . 1 7 2 7}$ & $<0.001^{* * *}$ \\
Species + TC + BF & 12.1 & 0.0 & 6.0 & 0.1000 & $<0.001^{* * *}$ \\
Species + CBH + BF & 14.6 & $<0.001$ & 6.0 & 0.1014 & $<0.001^{* * *}$ \\
Species + pH + BF & 15.1 & $<0.001$ & 6.0 & -0.0166 & $<0.001^{* * *}$ \\
Species + H + BF & 17.6 & $<0.001$ & 6.0 & 0.0257 & $<0.001^{* * *}$ \\
Species + BF & 19.4 & $<0.001$ & 5.0 & -0.0264 & $<0.001^{* * *}$ \\
Species + TC + CBH & 45.6 & $<0.001$ & 6.0 & -0.0632 & $<0.001^{* * *}$ \\
Species + CBH + pH & 51.2 & $<0.001$ & 6.0 & -0.2577 & $<0.001^{* * *}$ \\
Species + CBH + H & 51.9 & $<0.001$ & 6.0 & -0.3173 & $<0.001^{* * *}$ \\
Species + CBH & 55.5 & $<0.001$ & 5.0 & -0.2529 & $<0.001^{* * *}$ \\
Species + TC + H & 56.3 & $<0.001$ & 6.0 & -0.2043 & $0.0044^{* *}$ \\
Species + TC + pH & 56.4 & $<0.001$ & 6.0 & -0.3756 & $0.0197^{*}$ \\
Species + TC & 60.8 & $<0.001$ & 5.0 & -0.3798 & $0.0051^{* *}$ \\
Species + H + pH & 62.1 & $<0.001$ & 6.0 & -0.3817 & 0.1889 \\
Species + H & 66.5 & $<0.001$ & 5.0 & 0.0903 & 0.0692 \\
Species + pH & 66.9 & $<0.001$ & 5.0 & -0.5812 & 0.9855 \\
Species & 71.3 & $<0.001$ & 4.0 & -0.5831 & - \\
\hline
\end{tabular}


Table 4. Cont

\begin{tabular}{|c|c|c|c|c|c|}
\hline Model & $\Delta \mathrm{AICc}$ & wAIC & $\mathbf{k}$ & $\beta$ & $p$ \\
\hline \multicolumn{6}{|c|}{ Center } \\
\hline Species & 0.0 & 1.0 & 4.0 & 0.9667 & $<0.001^{* * *}$ \\
\hline Species $+\mathrm{TC}+\mathrm{CBH}+H+\mathrm{pH}+\mathrm{BF}$ & 268.7 & $<0.001$ & 9.0 & -6.675 & $<0.001^{* * *}$ \\
\hline Species $+\mathrm{TC}+\mathrm{BF}$ & 281.8 & $<0.001$ & 6.0 & -6.552 & $<0.001^{* * *}$ \\
\hline Species + pH + BF & 284.1 & $<0.001$ & 6.0 & -6.243 & $<0.001^{* * *}$ \\
\hline Species $+\mathrm{CBH}+\mathrm{BF}$ & 285.7 & $<0.001$ & 6.0 & -6.077 & $<0.001^{* * *}$ \\
\hline Species $+H+\mathrm{BF}$ & 287.2 & $<0.001$ & 6.0 & -5.865 & $<0.001^{* * *}$ \\
\hline Species + BF & 290.1 & $<0.001$ & 5.0 & -6.153 & $0.0018 * *$ \\
\hline Species $+\mathrm{TC}+\mathrm{CBH}$ & 294.4 & $<0.001$ & 6.0 & -6.319 & $0.0087^{* *}$ \\
\hline Species $+\mathrm{CBH}+\mathrm{pH}$ & 296.1 & $<0.001$ & 6.0 & -5.999 & 0.0677 \\
\hline Species $+\mathrm{TC}+\mathrm{pH}$ & 298.7 & $<0.001$ & 6.0 & -6.511 & $0.0126^{*}$ \\
\hline Species $+\mathrm{CBH}+H$ & 298.9 & $<0.001$ & 6.0 & -6.127 & $0.0320 *$ \\
\hline Species $+\mathrm{TC}+H$ & 299.9 & $<0.001$ & 6.0 & -5.892 & 0.0994 \\
\hline Species $+H+$ pH & 300.7 & $<0.001$ & 6.0 & -5.537 & $0.0036 * *$ \\
\hline Species $+\mathrm{CBH}$ & 301.9 & $<0.001$ & 5.0 & -5.909 & $0.0384 *$ \\
\hline Species + TC & 304.6 & $<0.001$ & 5.0 & 1.015 & 0.2902 \\
\hline Species $+\mathrm{pH}$ & 306.3 & $<0.001$ & 5.0 & -6.1 & 0.0819 \\
\hline Species $+H$ & 307.2 & $<0.001$ & 5.0 & -5.468 & - \\
\hline \multicolumn{6}{|c|}{ Edge } \\
\hline Species $+\mathrm{TC}+\mathrm{CBH}+H+\mathrm{pH}+\mathrm{BF}$ & 0.0 & 0.9845 & 9.0 & 0.1119 & 0.1161 \\
\hline Species $+\mathrm{pH}+\mathrm{BF}$ & 10.8 & 0.0045 & 6.0 & 0.2575 & 0.0529 \\
\hline Species $+H+B F$ & 11.1 & 0.0038 & 6.0 & 0.07919 & $0.0161 *$ \\
\hline Species + TC + BF & 12.5 & 0.0019 & 6.0 & 0.3047 & 0.0536 \\
\hline Species $+\mathrm{CBH}+\mathrm{BF}$ & 13.0 & 0.0015 & 6.0 & 0.2503 & 0.0343 * \\
\hline Species $+H+\mathrm{pH}$ & 13.7 & 0.0011 & 6.0 & 0.8233 & 0.2949 \\
\hline Species $+\mathrm{TC}+\mathrm{pH}$ & 14.2 & $<0.001$ & 6.0 & 1.014 & 0.6127 \\
\hline Species $+\mathrm{TC}+H$ & 15.1 & $<0.001$ & 6.0 & 0.8754 & 0.2484 \\
\hline Species $+\mathrm{CBH}+\mathrm{pH}$ & 15.9 & $<0.001$ & 6.0 & 0.9873 & 0.7215 \\
\hline Species + BF & 16.0 & $<0.001$ & 5.0 & 0.2565 & 0.0177 * \\
\hline Species $+\mathrm{CBH}+H$ & 16.6 & $<0.001$ & 6.0 & 0.7969 & 0.3417 \\
\hline Species $+\mathrm{TC}+\mathrm{CBH}$ & 17.1 & $<0.001$ & 6.0 & 1.036 & 0.5359 \\
\hline Species $+\mathrm{pH}$ & 18.2 & $<0.001$ & 5.0 & 0.967 & 0.6318 \\
\hline Species $+H$ & 19.0 & $<0.001$ & 5.0 & 0.8278 & 0.1503 \\
\hline Species + TC & 19.4 & $<0.001$ & 5.0 & 1.015 & 0.3770 \\
\hline Species + CBH & 21.0 & $<0.001$ & 5.0 & 0.9874 & 0.4951 \\
\hline Species & 23.3 & $<0.001$ & 4.0 & 0.9667 & - \\
\hline
\end{tabular}

* Significant at $5 \%$; ** Significant at $1 \%$; *** Significant at $0.1 \%$.

The dendrogram of the phytosociological variables, lichen, and host plant species revealed a major cluster formed primarily by the edge sites, that is, the edge of the CER, SSF, and ENP, as well as the center of the ENP (Figure 5). Clearly, the edge and center of the ENP were much more similar to one another than to any of the other sites, while the presence of the CER in this cluster was determined by the similarity of this formation with the vegetation of the ENP. The other cluster was formed by the center sites of the SSC, CER, and SSF fragments, associated with the edge of the SSC. 


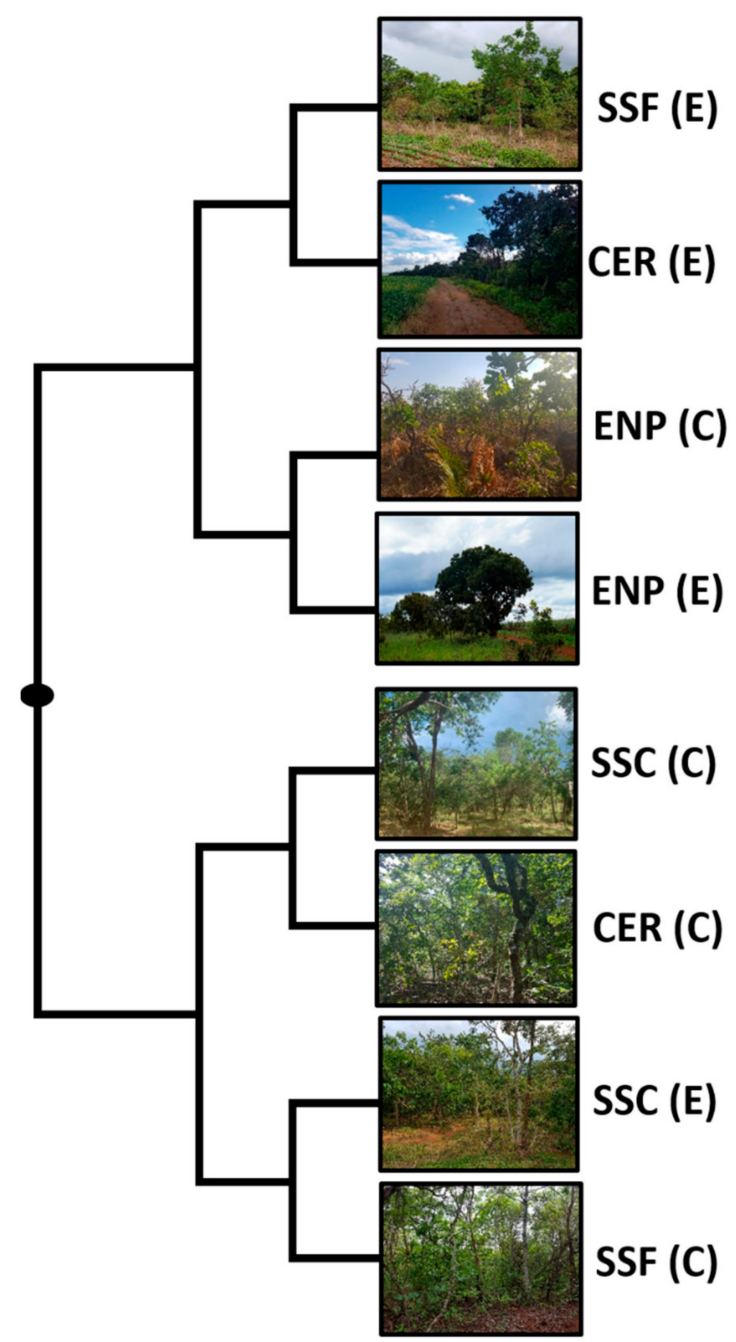

Figure 5. Dendrogram of the mean distance (UPGMA) of the phytosociological variables $(\mathrm{CBH}=$ Circumference at breast height; $H=$ height; $\mathrm{pH}=\mathrm{pH}$ of the bark; $\mathrm{TC}=$ Total Chlorophyll; $\mathrm{BF}=$ Bark fissures, and Lum = Illuminance), lichen (abundance of the different lichen morphotypes and percentage trunk cover) and host plant species sampled at the center (C) and edge (E) sites of three fragments of Cerrado and the Emas National Park (ENP).

\section{Discussion}

In the present study, dimorphic lichen was observed only in the center of the ENP, and the fruticose lichen was also more frequent in this area, which is consistent with the general patterns that show that the protection of habitat within conservation units benefits an ample range of species [58,59]. Gray et al. [60] demonstrated that lichen species richness is $10.6 \%$ higher and abundance $14.5 \%$ greater in samples from protected areas, in comparison with those collected outside these areas. Even so, a number of doubts persist with regard to the long-term success of protected areas [61]. Brown et al. [62] demonstrated that, even with protected status, small forest fragments may be unable to provide adequate protection, and that the annual composition of forest lichen species is highly dynamic. In fact, in the present study, we observed the greatest total frequency of lichen morphotypes in the center and edge of the SSC fragment, an area not under any type of protection. Similarly, the highest diversity $\left(H^{\prime}\right)$ was verified in the CER fragment, which is also not a protected area. This emphasizes the importance of the diversity found outside conservation units, as well as the establishment of new protected areas within the state of Goiás to better preserve the biodiversity of the Cerrado biome.

Although the whole of Goiás is located within the Cerrado domain, which has been designated a global conservation hotspot [63], $42.5 \%$ of the state is now covered in cattle pasture, and only $4.89 \%$ of 
the total area of the state is located within conservation units [64]. The ongoing expansion of intensive agriculture in the state exerts intense pressure on the remnants of Cerrado vegetation $[65,66]$ and threatens the survival of both species and ecosystem services (see [67]). The ENP, for example, has come under constant pressure from the adjacent areas of farmland, which surround the whole of the park. The occurrence of bushfires is also common around the edge of the park, and human activities have altered radically the natural fire patterns in the park, principally during the dry season, and in the areas that border the farmland, pastures, and roads [68]. These fires do not impact the species composition of the woody flora (see $[69,70]$ ), and in fact, the edge site of the park is more similar to the center sites of the fragments than their edges, as shown in the dendrogram (Figure 5). However, fires destroy the herbaceous vegetation and affect the corticolous lichen community, which colonizes the twisted trunks of the trees of the Cerrado sensu stricto. Mistry et al. [71,72] and also Mistry and Berardi [73] showed that fire is one of the principal determinants of the abundance and distribution of epiphytic lichen communities in the Cerrado. This would account for the fact that the edge site of the park has a lower mean lichen richness and percentage trunk cover than the center site. The mean cover at the edge of the ENP was also less than that of the edge sites in the other fragments combined. The high degree of impact observed at the edge of the park also reduced its diversity $\left(H^{\prime}\right)$ to levels similar to those found in the unprotected areas.

The greater frequency of lichen morphotypes in the center of the fragments, as well as the absence of morphotypes that are highly sensitive to disturbance from the edge areas, confirms our hypothesis of the existence of edge effects provoked by pesticide drift from the adjacent farmland matrix, that is, the edge areas are more affected than those more toward the center of the fragments. Edge effects have already been confirmed in an ample range of animal and plant species (e.g., [74-76]) and in lichen (e.g., $[17,77])$, although the present study is the first to provide evidence of edge effects in the lichen morphotypes found in natural remnants of Cerrado vegetation.

The response of lichen to edge effects is clear from the local extinction of some morphotypes, which become more restricted to habitats with low levels of disturbance [78]. Other morphotypes may become less diverse and dominated by species that are more resistant to disturbed environments $[79,80]$. The lichen morphotypes most resistant to impacted environments are, in decreasing order, crustose $>$ foliose $>$ fruticose $>$ dimorphic $>$ filamentous [81], which means that the presence and greater diversity of fruticose and dimorphic lichen in the central area of the ENP indicate that this was the least impacted of the study areas. In fact, this site is further from the edge than the central sites surveyed in the other fragments, and would thus be less likely to be affected by pesticide drift from the farmland matrix. However, we found a greater number of foliose than crustose morphotypes in two of the edge areas, a similar result to Benítez et al. [49], who observed a greater number of foliose lichen in disturbed areas.

The foliose morphotype was the most frequent lichen in all the fragments surveyed. A similar predominance of this morphotype has been recorded in other areas of Cerrado sensu stricto and in the forests of southern Brazil (e.g., [82-85]). A pattern of competition between the foliose and crustose morphotypes was observed in the edge areas of the fragments, with the foliose morphotypes being more common where the crustose types were rarer, and vice versa. It thus seems likely that, when one of these lichen morphotypes is established first, it spreads rapidly and hampers the colonization of the other morphotype. Armstrong and Welch [86] showed that lichen species may be excluded from a substrate through competition and that competitive interactions in diverse lichen communities can lead to the establishment of stable species groups. Competition may also account for the fact that the greater number of lichen morphotypes observed in the center of the ENP did not result in greater richness or cover. In fact, lichens produce allelopathic compounds [87], primarily phenols, that inhibit the establishment or development of other lichens (e.g., [88,89]), mosses (e.g., [90-92]), and even higher plants (e.g., [93,94]).

In addition to environmental disturbance and allelopathic interactions, the structure of the substrate may also influence the presence of corticolous lichen. For example, trees of a larger girth, at both the edge and the center of the fragments, were richer in lichen morphotypes, and more acidic 
bark tended to have greater lichen cover. Similarly, more fissured bark appears to be less adequate for the establishment and propagation of lichen morphotypes. Degtjarenko et al. [95] showed that foliose lichen, in particular, prefer more acidic substrates, and a number of other studies have shown a correlation between CBH and BF and the composition of the lichen found on the trunks $[47,96,97]$. However, Spier et al. [98] elucidated that, when analyzed alone, bark characteristics may not present a significant effect on the composition of the lichen found on the trunk, and that the tree species may be a more important factor.

In fact, when we evaluated the explanatory models for the patterns of total lichen morphotype richness, the model that included only the tree species was the most plausible, but when the center and edge were evaluated separately, this variable was associated with the $\mathrm{pH}$ in the center and $\mathrm{CBH}$ $+\mathrm{pH}$ at the edge. The model based on the variable Species was also the most appropriate model for the lichen cover in the center of the fragments. Uliczka and Angelstam [99] demonstrated that different lichen morphotypes presented a preference for different tree species in a study of 17 lichen species in a boreal forest ecosystem, with six of these species occurring exclusively on the trunks of Populus tremula. Variation in the frequency and abundance of lichens among different tree species is probably at least partly due to characteristics such as the texture and chemical constitution of the bark or environmental variables, such as illuminance, which may be influenced differentially by tree species [100]. However, the model that included all the study variables best explained the variation found in the total lichen cover at the edge sites, which implies that all these variables are important, to some degree, as determinants of the percentage cover of the trunks.

Despite the selective pressures known to be exerted by environmental and substrate variables on the lichen community, the present study is the first to confirm the role of edge effects on the occurrence of the different lichen morphotypes found in the remnants of the natural vegetation of the Cerrado biome. The study has also shown how this edge effect reflects the impacts of pesticide drift from the farmland matrix on the lichen found in these fragments. We believe that the high sensitivity of lichens to pollutants determines that they respond differently to edge effects, even in very small fragments of vegetation. The present study has thus provided important insights for future research that tests how lichens respond to edge effects in fragments of different sizes.

\section{Conclusions}

Dimorphic lichen and a greater frequency of fruticose lichen were found at the center of the ENP, which indicates that protected areas are important for the preservation of the lichen communities that are more sensitive to the impacts resulting from pesticide drift in areas of edge habitat. In the fragments, the central areas were richer in corticolous lichen morphotypes and the trunks had greater lichen cover, which indicates that these areas are more stable. We also confirmed that the lichen richness and cover may be influenced by phytosociological factors, such as the tree girth, the fissuring of the bark, and its $\mathrm{pH}$. We also confirmed that the intrinsic characteristics of the tree species may influence lichen colonization patterns and the distribution of the morphotypes on the stem of the host. We confirmed our hypothesis that the agricultural matrix affects the characteristics of the corticolous lichen community through pesticide drift, which modifies both the composition and diversity of the lichen in areas of edge habitat. However, given the importance of the lichen for the monitoring of ecosystems and the evaluation of impacts on other species, further studies are needed to determine the effects of the agricultural matrix on groups such as the microbial communities or the higher plants, which may also be impacted directly by agricultural pollutants.

Supplementary Materials: The following are available online at http://www.mdpi.com/2071-1050/12/17/7149/s1, Table S1: Frequency of plant species sampled in the center and edge (E) sites in the three Cerrado fragments (Cerradão-CER, Seasonal Semideciduous Forest-SSF, and Cerrado sensu stricto-SSC) and the Emas National Park-ENP, in Southwestern Goiás, central Brazil. Table S2. Mean values of the CBH = Circumference at breast height; $\mathrm{H}=$ height; $\mathrm{pH}=\mathrm{pH}$ of the bark; $\mathrm{TC}=$ Total Chlorophyll; $\mathrm{BF}=$ Bark fissures, and Lum = Illuminance, recorded in the center and edge of three fragments, Cerradão (CER), Seasonal Semi-deciduous Forest (SSF), and Cerrado sensu stricto (SSC), and the Emas National Park (ENP). 
Author Contributions: Conceptualization, L.C.V.; methodology, L.C.V. and K.M.Z.P.; formal analysis, K.M.Z.P. and G.C.d.O.M.; investigation, K.M.Z.P.; resources, L.A.B.; writing-original draft preparation, K.M.Z.P.; writing-review and editing, L.C.V. and L.A.B.; supervision, L.A.B. All authors have read and agreed to the published version of the manuscript.

Funding: This research received no external funding.

Acknowledgments: We are grateful to the Goiás State Research Foundation (FAPEG) for masters stipends, and the Rio Verde campus of the Goiano Federal Institute (IFGoiano), for providing the infrastructure necessary for the realization of the present study. We would also like to thank Drs. Patrícia Oliveira da Silva and Michellia Pereira Soares for kindly identifying the tree species observed in the present study.

Conflicts of Interest: The authors declare no conflict of interest.

\section{References}

1. Rubio-Salcedo, M.; Psomas, A.; Prieto, M.; Zimmermann, N.E.; Martínez, I. Case study of the implications of climate change for lichen diversity and distributions. Biodivers. Conserv. 2016, 26, 1121-1141. [CrossRef]

2. McMurray, J.A.; Roberts, D.W.; Geiser, L.H. Epiphytic lichen indication of nitrogen deposition and climate in the northern rocky mountains, USA. Ecol. Indic. 2015, 49, 154-161. [CrossRef]

3. Root, H.T.; Geiser, L.H.; Jovan, S.; Neitlich, P. Epiphytic macrolichen indication of air quality and climate in interior forested mountains of the Pacific Northwest, USA. Ecol. Indic. 2015, 53, 95-105. [CrossRef]

4. Matos, P.; Geiser, L.; Hardman, A.; Glavich, D.; Pinho, P.; Nunes, A.; Soares, A.M.V.M.; Branquinho, C. Tracking global change using lichen diversity: Towards a global-scale ecological indicator. Methods Ecol. Evol. 2017, 8, 788-798. [CrossRef]

5. Sett, R.; Kundu, M. Epiphytic lichens: Their usefulness as bio-indicators of air pollution. Donnish J. Res. Environ. Stud. 2016, 3, 17-24.

6. Koch, N.M.; Matos, P.; Branquinho, C.; Pinho, P.; Lucheta, F.; de Azevedo Martins, S.M.; Ferrão Vargas, V.M. Selecting lichen functional traits as ecological indicators of the effects of urban environment. Sci. Total Environ. 2019, 654, 705-713. [CrossRef] [PubMed]

7. Matos, P.; Vieira, J.; Rocha, B.; Branquinho, C.; Pinho, P. Modeling the provision of air-quality regulation ecosystem service provided by urban green spaces using lichens as ecological indicators. Sci. Total Environ. 2019, 665, 521-530. [CrossRef] [PubMed]

8. Cardós, J.L.H.; Martínez, I.; Calvo, V.; Aragón, G. Epiphyte communities in Mediterranean fragmented forests: Importance of the fragment size and the surrounding matrix. Landsc. Ecol. 2016, 31, 1975-1995. [CrossRef]

9. Cardós, J.L.H.; Aragón, G.; Martínez, I. A species on a tightrope: Establishment limitations of an endangered lichen in a fragmented Mediterranean landscape. Am. J. Bot. 2017, 104, 527-537. [CrossRef] [PubMed]

10. Franklin, J.F.; Cromack, K., Jr.; Denison, W.; McKee, A.; Maser, C.; Sedetl, J.; Swanson, F.; Juday, G. Ecological Characteristics of Old-Growth Douglas-Fir Forests; General Technical Report PNW-GTR-118; U.S. Department of Agriculture, Forest Service: Portland, OR, USA, 1981; pp. 1-48. [CrossRef]

11. Couvet, D. Deleterious effects of restricted gene flow in fragmented populations. Conserv. Biol. 2002, 16, 369-376. [CrossRef]

12. Murphy, H.T.; Lovett-Doust, J. Context and connectivity in plant metapopulations and landscape mosaics: Does the matrix matter? Oikos 2004, 105, 3-14. [CrossRef]

13. Driscoll, D.A.; Banks, S.C.; Barton, P.S.; Lindenmayer, D.B.; Smith, A.L. Conceptual domain of the matrix in fragmented landscapes. Trends Ecol. Evol. 2013, 28, 605-613. [CrossRef] [PubMed]

14. Fahrig, L. How much habitat is enough? Biol. Conserv. 2001, 100, 65-74. [CrossRef]

15. Liepa, L.; Straupe, I. Edge effects on epiphytic lichens in unmanaged black alder stands in Southern Latvia. Res. Rural Dev. 2015, 2, 44-49.

16. Barry, M.; McMullin, R.T.; Horn, A. Edge effects on the lichen genus Lobaria in Atlantic Canadian Forests. Forest. Chron. 2015, 91, 534-540. [CrossRef]

17. Aragón, G.; Abuja, L.; Belinchón, R.; Martínez, I. Edge type determines the intensity of forest edge effect on epiphytic communities. Eur. J. For. Res. 2015, 134, 443-451. [CrossRef]

18. Ratter, J.A.; Ribeiro, J.F.; Bridgewater, S. The Brazilian Cerrado vegetation and threats to its biodiversity. Ann. Bot. 1997, 80, 223-230. [CrossRef]

19. Eaten, G. The cerrado vegetation of Brazil. Bot. Rev. 1972, 38, 201-341. [CrossRef] 
20. Chen, Y.; Wen, X.; Wang, B.; Nie, P. Agricultural pollution and regulation: How to subsidize agriculture? J. Clean. Prod. 2017, 164, 258-264. [CrossRef]

21. Roseiro, M.N.V.; Takanavanagui, A.M.M. Meio ambiente e poluição atmosférica: O caso da cana-de-açúcar. Rev. Do Cent. De Ciências Da Saúde 2004, 30, 73-86. [CrossRef]

22. Langenbach, T.; Mano, D.; Campos, M.M.; Cunha, A.L.M.C.; De Campos, T.M.P. Pesticide dispersion by spraying under tropical conditions. J. Environ. Sci. Health B 2017, 52, 843-849. [CrossRef] [PubMed]

23. Sousa, M.G.F.; da Silva, A.C.; dos Santos Araújo, R.; Rigotto, R.M. Evaluation of the atmospheric contamination level for the use of herbicide glyphosate in the northeast region of Brazil. Environ. Monit. Assess. 2019, 191, 604. [CrossRef] [PubMed]

24. Di Martos, L.M.; Jost, C.L. Sequential determination of five heavy metal ions in Brazilian phosphate fertilizers and surface waters by stripping voltammetry. Int. J. Environ. Sci. Technol. 2019. [CrossRef]

25. Rangel, M.G.L.; Henríquez, J.R.; Costa, J.A.P.; de Lira Junior, J.C. An assessment of dispersing pollutants from the pre-harvest burning of sugarcane in rural areas in the northeast of Brazil. Atmos. Environ. 2018, 178, 265-281. [CrossRef]

26. Nacke, H.; Gonçalves, A.C.; Schwantes, D.; Nava, I.A.; Strey, L.; Coelho, G.F. Availability of heavy metals $(\mathrm{Cd}, \mathrm{Pb}$, and $\mathrm{Cr})$ in agriculture from commercial fertilizers. Arch. Environ. Contam. Toxicol. 2013, 64, 537-544. [CrossRef] [PubMed]

27. Zoffoli, H.J.O.; do Amaral-Sobrinho, N.M.B.; Zonta, E.; Luisi, M.V.; Marcon, G.; Tolón-Becerra, A. Inputs of heavy metals due to agrochemical use in tobacco fields in Brazil's Southern Region. Environ. Monit. Assess. 2013, 185, 2423-2437. [CrossRef] [PubMed]

28. Cáceres, M.E.S.; Aptroot, A.; Lücking, R. Lichen fungi in the Atlantic rain forest of Northeast Brazil: The relationship of species richness with habitat diversity and conservation status. Braz. J. Bot. 2016, 40, 145-156. [CrossRef]

29. López, L.G.C.; Medina, E.A.S.; Peña, A.M. Effects of microclimate on species diversity and functional traits of corticolous lichens in the Popayan Botanical Garden (Cauca, Colombia). Cryptogam. Mycol. 2016, 37, 205-215. [CrossRef]

30. Käffer, M.; Koch, N.; Martins, S.; Vargas, V. Lichen community versus host tree bark texture in an urban environment in southern Brazil. Iheringia Ser. Bot. 2016, 71, 49-54.

31. Abas, A.; Nizam, M.S. Elevated $\mathrm{CO}_{2}$ effects on corticolous lichen and bark $\mathrm{pH}$ in free-air $\mathrm{CO}_{2}$ enrichments (FACE) station. Adv. Environ. Biol. 2017, 11, 68-72.

32. Rasmussen, H.N.; Nord-Larsen, T.; Hansen, E.S.; Hoareau, G. Estimation of life history in corticolous lichens by zonation. Lichenologist 2018, 50, 697-704. [CrossRef]

33. Simijaca, D.; Moncada, B.; Lücking, R. Oak forest or conifer plantation, what do epiphytic lichens prefer? Colomb. For. 2018, 21, 123-141. [CrossRef]

34. Yatawara, M.; Dayananda, N. Use of corticolous lichens for the assessment of ambient air quality along rural-urban ecosystems of tropics: A study in Sri Lanka. Environ. Monit. Assess. 2019, 191, 179. [CrossRef] [PubMed]

35. Perlmutter, G.B.; Blank, G.B.; Wentworth, T.R.; Lowman, M.D.; Neufeld, H.S.; Plata, E.R. Highway pollution effects on microhabitat community structure of corticolous lichens. Bryologist 2018, 121, 1-13. [CrossRef]

36. Millar, R.B.; Anderson, M.J. Remedies for pseudoreplication. Fish. Res. 2004, 70, 397-407. [CrossRef] [PubMed]

37. Bolker, B.M.; Brooks, M.E.; Clark, C.J.; Geange, S.W.; Poulsen, J.R.; Stevens, M.H.H.; White, J.S. Generalized linear mixed models: A practical guide for ecology and evolution. Trends Ecol. Evol. 2009, 24, 127-135. [CrossRef] [PubMed]

38. Holt, R.D.; Keitt, T.H. Species' borders: A unifying theme in ecology. Oikos 2005, 108, 3-6. [CrossRef]

39. Ribeiro, J.F.; Walter, B.M. Tdo bioma Cer. Fitofisionomias rado. In Cerrado: Ambiente e Flora. Planaltina; Sano, S.M., Almeida, S.P., Eds.; Embrapa-CPAC: Brasília, Brazil, 1998; pp. 87-166.

40. Kilca, R.V.; Schiavini, I.; Monteiro, G.A. Floristic patterns on two seasonal forests types in the Cerrado. Biosci. J. 2014, 30, 903-913.

41. Schlichting, A.F.; Bonfim-Silva, E.M.; Silva, M.C.; Pietro-Souza, W.; da Silva, T.J.A.; Farias, L.N. Efficiency of portable chlorophyll meters in assessing the nutritional status of wheat plants. Rev. Bras. Eng. Agríc. Ambient 2015, 19, 1148-1151. [CrossRef] 
42. Silva Júnior, M.C. 100 Árvores do Cerrado Sentido Restrito: Guia de Campo; Rede de Sementes do Cerrado: Brasília, Brazil, 2012; pp. 1-360.

43. Silva Júnior, M.C.; Pereira, B.D.S. 100 Árvores do Cerrado-Matas de Galeria: Guia de Campo; Rede de Sementes do Cerrado: Brasília, Brazil, 2009; pp. 1-288.

44. Kuhlmann, M. Frutos e Sementes do Cerrado: Espécies Atrativas Para A Fauna; Ipsis Gráfica e Editora: Brasília, Brazil, 2018; pp. 1-464.

45. APG IV. An update of the Angiosperm Phylogeny Group classification for the orders and families of flowering plants: APG IV. Bot. J. Linn. Soc. 2016, 181, 1-20. [CrossRef]

46. Kricke, R. Measuring Bark pH. In Monitoring with Lichens-Monitoring Lichens; Nimis, P.L., Scheidegger, C., Wolseley, P.A., Eds.; Kluwer Academic Publishers: Dordrecht, The Netherlands, 2002; pp. 333-336. [CrossRef]

47. McDonald, L.; Van Woudenberg, M.; Dorin, B.; Adcock, A.M.; McMullin, R.T.; Cottenie, K. The effects of bark quality on corticolous lichen community composition in urban parks of southern Ontario. Botany 2017, 95, 1141-1149. [CrossRef]

48. Ferreira, T.; Rasband, W. O ImageJ Guia do Usuário-Version 1.43. 2010. Available online: http://rsbweb.nih. gov/ij/docs/user-guide.pdf (accessed on 1 February 2020).

49. Benítez, A.; Aragón, G.; González, Y.; Prieto, M. Functional traits of epiphytic lichens in response to forest disturbance and as predictors of total richness and diversity. Ecol. Indic. 2018, 86, 18-26. [CrossRef]

50. Shannon, C.E. A mathematical theory of communication. Bell Syst. Tech. J. 1948, 27, 379-423. [CrossRef]

51. Nagendra, H. Opposite trends in response for the Shannon and Simpson indices of landscape diversity. Appl. Geogr. 2002, 22, 175-186. [CrossRef]

52. R Core Team. R: A Language and Environment for Statistical Computing. R Foundation for Statistical Computing. Available online: https://www.R-project.org/ (accessed on 30 January 2020).

53. Hadfield, J.D. Package 'MCMCglmm', MCMC Generalised Linear Mixed Models, Version 2.29. 2019. Available online: https://cran.r-project.org/web/packages/MCMCglmm/MCMCglmm.pdf (accessed on 12 February 2020).

54. Hadfield, J.D. MCMC methods for Multi-response Generalised Linear Mixed Models: The MCMCglmm R Package. J. Stat. Softw. 2010, 33, 1-22. [CrossRef]

55. Burnham, K.P.; Anderson, D.R. Model. Selection and Multi-Model Inference; Springer: Detroit, MI, USA, 2002; pp. 1-487.

56. Sokal, R.R.; Rohlf, F.J. The comparison of dendrograms by objective methods. Taxon 1962, 11, 33. [CrossRef]

57. Garcia-Vallve, S.; Palau, J.; Romeu, A. Horizontal gene transfer in glycosyl hydrolases inferred from codon usage in Escherichia coli and Bacillus subtilis. Mol. Biol. Evol. 1999, 16, 1125-1134. [CrossRef] [PubMed]

58. Geldmann, J.; Barnes, M.; Coad, L.; Craigie, I.D.; Hockings, M.; Burgess, N.D. Effectiveness of terrestrial protected areas in reducing habitat loss and population declines. Biol. Conserv. 2013, 161, 230-238. [CrossRef]

59. Coetzee, B.W.T.; Gaston, K.J.; Chown, S.L. Local scale comparisons of biodiversity as a test for global protected area ecological performance: A meta-analysis. PLoS ONE 2014, 9, e105824. [CrossRef] [PubMed]

60. Gray, C.L.; Hill, S.L.L.; Newbold, T.; Hudson, L.N.; Börger, L.; Contu, S.; Hoskins, A.J.; Ferrier, S.; Purvis, A.; Scharlemann, J.P.W. Local biodiversity is higher inside than outside terrestrial protected areas worldwide. Nat. Commun. 2016, 7, 12306. [CrossRef] [PubMed]

61. Rayner, L.; Lindenmayer, D.B.; Wood, J.T.; Gibbons, P.; Manning, A.D. Are protected areas maintaining bird diversity? Ecography 2013, 37, 43-53. [CrossRef]

62. Brown, J.A.; Lockwood, J.L.; Avery, J.D.; Curtis Burkhalter, J.; Aagaard, K.; Fenn, K.H. Evaluating the long-term effectiveness of terrestrial protected areas: A 40-year look at forest bird diversity. Biodivers. Conserv. 2019. [CrossRef]

63. Myers, N.; Mittermeier, R.A.; Mittermeier, C.G.; da Fonseca, G.A.B.; Kent, J. Biodiversity hotspots for conservation priorities. Nature 2000, 403, 853-858. [CrossRef] [PubMed]

64. Novaes, P.C.; Ferreira, L.G.; Dias, R. Identificação de áreas prioritárias para conservação da biodiversidade do estado de Goiás. Bol. Goiano De Geogr. 2003, 23, 41-58. [CrossRef]

65. Mantovani, J.E.; Pereira, A. Estimativa da integridade da cobertura de vegetação do cerrado através de dados Landsat-TM. In Proceedings of the Simpósio Brasileiro de Sensoriamento Remoto 9, Santos, Brazil, 11-18 September 1998; pp. 1455-1466.

66. Sano, E.E.; Barcellos, A.O.; Bezerra, H.S. Assessing the spatial distribution of cultivated pastures in the Brazilian savanna. Pasturas Trop. 2001, 22, 2-15. 
67. Latrubesse, E.M.; Arima, E.; Ferreira, M.E.; Nogueira, S.H.; Wittmann, F.; Dias, M.S.; Dagosta, F.; Bayer, M. Fostering water resource governance and conservation in the Brazilian Cerrado biome. Conserv. Sci. Pract. 2019, 1, e77. [CrossRef]

68. França, H.; Ramos Neto, M.B.; Setzer, A. O Fogo no Parque Nacional das Emas; MMA, Ministério do Meio Ambiente: Brasília, Brazil, 2007; pp. 1-140.

69. Souchie, F.F.; Pinto, J.R.R.; Lenza, E.; Gomes, L.; Maracahipes-Santos, L.; Silvério, D.V. Post-fire resprouting strategies of woody vegetation in the Brazilian savanna. Acta Bot. Bras. 2017, 31, 260-266. [CrossRef]

70. Lenza, E.; Abadia, A.C.; Menegat, H.; Lúcio, N.W.; Marachipes-Santos, L.; Mews, H.A.; Santos, J.O.; Martins, J. Does fire determine distinct floristic composition of two Cerrado savanna communities on different substrates? Acta Bot. Bras. 2017, 31, 250-259. [CrossRef]

71. Mistry, J. Corticolous lichens as potential bioindicators of fire history: A study in the cerrado of the Distrito Federal, central Brazil. J. Biogeogr. 1998, 25, 409-441. [CrossRef]

72. Mistry, J. A preliminary lichen fire history (LFH) key for the Cerrado of the Distrito Federal, central Brazil. J. Biogeogr. 1998, 25, 443-452. [CrossRef]

73. Mistry, J.; Berardi, A. Effects of phorophyte determinants on lichen abundance in the cerrado of central Brazil. Plant. Ecol. 2005, 178, 61-76. [CrossRef]

74. Donoso, D.S.; Grez, A.A.; Simonetti, J.A. Effects of forest fragmentation on the granivory of differently sized seeds. Biol. Conserv. 2004, 115, 63-70. [CrossRef]

75. Alexander, H.M.; Price, S.; Houser, R.; Finch, D.; Tourtellot, M. Is there reduction in disease and pre-dispersal seed predation at the border of a host plant's range? Field and herbarium studies of Carex blanda. J. Ecol. 2007, 95, 446-457. [CrossRef]

76. Wang, K.; Zhou, H.; Wang, B.; Jian, Z.; Wang, F.; Huang, J.; Nie, L.; Cui, K.; Peng, S. Quantification of border effect on grain yield measurement of hybrid rice. Field Crops Res. 2013, 141, 47-54. [CrossRef]

77. Hauck, M. Edge effects on epiphytic lichen diversity in the forest-steppe of the Kazakh Altai. Plant Ecol. Divers. 2013, 7, 473-483. [CrossRef]

78. Will-Wolf, S.; Esseen, P.-A.; Neitlich, P. Monitoring biodiversity and ecosystem function: Forests. In Monitoring with Lichens-Monitoring Lichens; Nimis, P.L., Scheidegger, C., Wolseley, P.A., Eds.; Kluwer Academic Publishers: Dordrecht, The Netherlands, 2002; pp. 203-222. [CrossRef]

79. Jüriado, I.; Paal, J.; Liira, J. Epiphytic and epixylic lichen species diversity in Estonian natural forests. Biodivers. Conserv. 2003, 12, 1587-1607. [CrossRef]

80. Brunialti, G.; Giordani, P. Variability of lichen diversity in a climatically heterogeneous area (Liguria, NW Italy). Lichenologist 2003, 35, 55-69. [CrossRef]

81. Tripathi, M.; Joshi, Y. (Eds.) What are Lichenized Fungi? In Endolichenic Fungi: Present and Future Trends; Springer: Berlin/Heidelberg, Germany, 2019; pp. 1-26. [CrossRef]

82. Costa, W.R.; Mineo, M.F. Os líquens como bioindicadores de poluição atmosférica no município de Uberaba, Minas Gerais. Rev. Eletrônica Em Gestão Educ. E Tecnol. Ambient. 2013, 13, 2690-2700. [CrossRef]

83. Käffer, M.I.; Marcelli, M.P.; Ganade, G. Distribution and composition of the lichenized mycota on a landscape mosaic from southern Brazil. Acta Bot. Bras. 2010, 24, 790-802. [CrossRef]

84. Käffer, M.I.; Ganade, G.; Marcelli, M.P. Lichen diversity and composition in Araucaria forests and tree monocultures in southern Brazil. Biodivers. Conserv. 2009, 18, 3543-3561. [CrossRef]

85. Lemos, A.; Käffer, M.I.; Martins, S.A. Composição e diversidade de liquens corticícolas em três diferentes ambientes: Florestal, Urbano e Industrial. Rev. Bras. De Biociências 2007, 5, 228-230.

86. Armstrong, R.A.; Welch, A.R. Competition in lichen communities. Symbiosis 2007, 43, 1-12.

87. Goga, M.; Elečko, J.; Marcinčinová, M.; Ručová, D.; Bačkorová, M.; Bačkor, M. Lichen metabolites: An overview of some secondary metabolites and their biological potential. Co-Evol. Second. Metab. 2020, 1-36. [CrossRef]

88. Torzilli, A.P.; Mikelson, P.A.; Lawrey, J.D. Physiological effect of lichen secondary metabolites on the lichen parasite Marchandiomyces corallinus. Lichenologist 1999, 31, 307-314. [CrossRef]

89. Lawrey, J.D. Lichen Allelopathy: A Review. In Allelopathy-Organisms, Processes, and Applications; Inderjit Dakshini, K.M.M., Einhellig, F.A., Eds.; American Chemical Society: Washington, DC, USA, 1994; pp. 26-38. [CrossRef]

90. Goga, M.; Antreich, S.J.; Bačkor, M.; Weckwerth, W.; Lang, I. Lichen secondary metabolites affect growth of Physcomitrella patens by allelopathy. Protoplasma 2016, 254, 1307-1315. [CrossRef] [PubMed] 
91. Ručová, D.; Goga, M.; Sabovljević, M.; Vilková, M.; Petrul'ová, V.; Bačkor, M. Insights into physiological responses of mosses Physcomitrella patens and Pohlia drummondii to lichen secondary metabolites. Protoplasma 2019. [CrossRef] [PubMed]

92. Frahm, J.P.; Specht, A.; Reifenrath, K.; Vargas, Y.L. Allelopathic effect of crustaceous lichens on epiphytic bryophytes and vascular plants. Nova Hedwig. 2000, 70, 245-254. [CrossRef]

93. Favero-Longo, S.E.; Piervittori, R. Lichen-plant interactions. J. Plant. Interact. 2010, 5, 163-177. [CrossRef]

94. Pizňak, M.; Kolarčik, V.; Goga, M.; Bačkor, M. Allelopathic effects of lichen metabolite usnic acid on growth and physiological responses of Norway spruce and Scots pine seedlings. S. Afr. J. Bot. 2019, 124, 14-19. [CrossRef]

95. Degtjarenko, P.; Matos, P.; Marmor, L.; Branquinho, C.; Randlane, T. Functional traits of epiphytic lichens respond to alkaline dust pollution. Fungal Ecol. 2018, 36, 81-88. [CrossRef]

96. Fritz, O.; Brunet, J.; Caldiz, M. Interacting effects of tree charactersictics on the occurrence of rare epiphytes in a Swedish boreal forest. Bryologist 2009, 112, 488-505. [CrossRef]

97. Ranius, T.; Johansson, P.; Berg, N.; Niklasson, M. The influence of tree age and microhabitat quality on the occurrence of crustose lichens associated with old oaks. J. Veg. Sci. 2008, 19, 653-662. [CrossRef]

98. Spier, L.; van Dobben, H.; van Dort, K. Is bark pH more important than tree species in determining the composition of nitrophytic or acidophytic lichen floras? Environ. Pollut. 2010, 158, 3607-3611. [CrossRef] [PubMed]

99. Uliczka, H.; Angelstam, P. Occurrence of epiphytic macrolichens in relation to tree species and age in managed boreal forest. Ecography 1999, 22, 396-405. [CrossRef]

100. Lamit, L.J.; Bowker, M.A.; Holeski, L.M.; Næsborg, R.R.; Wooley, S.C.; Zinkgraf, M.; Lindroth, R.L.; Whitham, T.G.; Gehring, C.A. Genetically-based trait variation within a foundation tree species influences a dominant bark lichen. Fungal Ecol. 2011, 4, 103-109. [CrossRef]

(C) 2020 by the authors. Licensee MDPI, Basel, Switzerland. This article is an open access article distributed under the terms and conditions of the Creative Commons Attribution (CC BY) license (http://creativecommons.org/licenses/by/4.0/). 